\title{
OPTIMIZATION OF ENZYMATIC HYDROLYSIS CONDITIONS FOR INCREASING THE EFFICIENCY OF DRY MATTER EXTRACTED FROM Limonia acidissima PULP BY COMBINED CELLULASE -PECTINASE ENZYMES USING RESPONSE SURFACE METHODOLOGY
}

\author{
Pham Bao Nguyen ${ }^{1,}$, Dong Thi Anh Dao ${ }^{2}$ \\ ${ }^{I}$ Postharvest Technology center, Tra Vinh University, 126 Nguyen Thien Thanh street, Ward 5, \\ Tra Vinh city, Vietnam \\ ${ }^{2}$ Dept. Food Technology, Vietnam Nat. Uni. HCM University of Technology, \\ 268 Ly Thuong Kiet Street, Ward 14, District 10, HCMC, Vietnam \\ "Email:pbnguyen@tvu.edu.vn
}

Received: 27 November 2015; Accepted for publication: 1 December 2016

\begin{abstract}
The Limonia acidissima (L. acidissima) fruits are rich in nutrient values and bioactive compounds. The hydrolysis of $L$. acidissima pulp was researched by combined cellulase and pectinase enzymes to increase the yield of dry matter and bioactive compounds. In this study, the hydrolysis conditions by using the combined enzymes for increasing the dry matter recovery were optimized by response surface methodology (RSM). The independent variables were coded as: $\mathrm{pH}\left(\mathrm{x}_{1}\right)$, incubation temperature $\left(\mathrm{x}_{2}\right)$, the total content of combined cellulase-pectinase $\left(\mathrm{x}_{3}\right)$ (with the ratio of cellulase/pectinase was 1/1), and hydrolysis time $\left(\mathrm{x}_{4}\right)$. The results of the analysis of variance (ANOVA) showed that the variables actively affected the efficiency of extracted dry matter. The optimal conditions of hydrolysis were derived at $\mathrm{Z}_{1}=4.2, \mathrm{Z}_{2}=45^{\circ} \mathrm{C}$, $\mathrm{Z}_{3}=1.6 \%(\mathrm{v} / \mathrm{dwt}), \mathrm{Z}_{4}=120$ minutes. At the conditions, the efficiency of the prediction model reached $54.76 \%$ and it had no significant difference compared with experimental value (54.69 $\%)$. That increased $20.89 \%$ compared with the efficiency from the non-enzymatic extraction. Besides, the recovery efficiency of carbohydrate reached $87.74 \%$. Further, the content of extracted phenolic, carotenoids and DPPH and ABTS radical scavenging activity highly increased, which reached $106.7 \mathrm{mg}$ GAE, $86.6 \mathrm{mg}, 67.1$ and $102.1 \mathrm{mg}$ trolox equivalent antioxidant capacity (TEAC) from $100 \mathrm{~g}$ L. acidissima pulp, respectively.
\end{abstract}

Keywords: optimization, cellulase, pectinase, Limonia acidissima L., DPPH, ABTS radical scavenging activity.

\section{INTRODUCTION}

Limonia acidissima (syn. Wood apple, Feronia elephantum, Feronia limonia, Hesperethusa crenulata, Schinus limonia) is a tropical fruit from the family of Rutaceae. It is a tree yielding 
fruit which is popular in India, Sri Lanka, Pakistan, Bangladesh, Burma, Thailand, and most of the Southeast Asian countries [1]. It is one of the important plants that is used for traditional medicine [2]. The fruit is rich in nutrient compared with many other fruits [3]. The nutritional analysis of pulp proved that it contained a potential source of energy, protein and carbohydrate. Total dietary fiber in this fruit included insoluble dietary and soluble dietary fiber (mucilage and pectin). It also contained many vitamins and minerals including vitamin $\mathrm{C}$, vitamin $\mathrm{A}$, thiamine, riboflavin, niacin, $\mathrm{Ca}, \mathrm{P}[4,5], \mathrm{Na}, \mathrm{K}, \mathrm{Mg}, \mathrm{Zn}$ and $\mathrm{Cu}, \mathrm{Fe}[6]$. In addition, it is a medicinal plant, so it has been used widely because of the bioactive compounds such as carotenoids, phenolics, alkaloids, coumarins, and other antioxidants which may protect us against chronic diseases. The fruit is available plenty and a cheap source for the exploration of the development of nutraceuticals for diabetes [7, 8]. Positive correlation was observed between polyphenol content and the antioxidant capacities with enormous health benefits. That may be used in food and pharmaceutical applications [9]. Besides, the pulp exhibited good antibacterial activity against gram positive bacteria, antifungal, astringent, anti-inflammatory and insulin secretogouge activities. The antimicrobial activity could be mainly due to the presence of phenolic compounds, thymol. That widely reported to possess high levels of antimicrobial activity [10, 11]. Thymol has been shown to cause disruption of the cellular membrane or inhibition of ATPase activity and release of in tracellular ATP and other constituents [12]. That demonstrates that $L$. acidissima fruits may be used as nutraceuticals for disease prevention and health promoting benefits [4].

The pulp of L. acidissima fruits is also eaten raw or is blended with coconut milk and palmsugar syrup, and drunk as a beverage or nice cream [13]. Especially, the jam and jelly from wood apple are becoming popular in India and Sri Lanka. In India, the fruit was as a "poor man's food" until processing techniques were developed in the mid-1950s. The using demand of L. acidissima fruits has increased remarkably in the last few decades [3].

The fruit cell wall is degraded efficiently by a synergistic action of endopolygalacturonases and cellulases [14]. In particular, the use of cellulases and pectinases not only increases the recovery from juice but also ensures the quality of the end products $[15,16]$. These enzymes help in softening the plant tissue and lead to the release of cell contents. That may be recovered with high yield [17]. Hence, the combination of cellulase and pectinase was used to increase the yield and quality of the extract from L. acidissima pulp.

The experimental design by traditional method to find out the optimal values of variables is usually based on individual factors and time-consuming. So it can easily lead to incorrect conclusions as there are many factors having impact at the same time on the objective function. Response surface methodology (RSM), a statistical experimental design which is used in mathematical model, can be effectively applied to optimize biochemical processes. It not only describes the interaction between independent variables on the objective function but also build regression equation expressing the relationship between it. Through which can predict and control the processes. Currently, RSM is being applied to extract bioactive compounds from Feronia limonia L. using solvent (alcohol) [10], polysaccharides from Lycium ruthenicum fruit using water [18], polysaccharides from Cornus officinalis using enzyme [19].

The aim of this study was to optimize the enzymatic hydrolysis conditions ( $\mathrm{pH}$, incubation temperature, cellulase and pectinase concentration and hydrolysis time). Furthermore, we studied the effect of hydrolysis to the recovery of phenolic compounds, carotenoids content, DPPH and ABTS radical scavenging activities. 


\section{MATERIALS AND METHODS}

\subsection{Materials}

\subsubsection{Chemicals}

1,1-Diphenyl-2-picryl-hydrazyl (DPPH); 2,2'-azino-bis (3-ethylbenzthiazoline-6-sulphonic acid (ABTS); 6-hydroxy-2,5,7,8-tetramethyl-chroman-2-carboxylic acid (Trolox) and Potassium persulfate $\left(\mathrm{K}_{2} \mathrm{~S}_{2} \mathrm{O}_{8}\right)$ was purchased from Sigma-Aldrich, USA; BioBasic, Canada; SigmaAldrich, USA and China.

\subsubsection{Enzymes}

Commercial enzymes, Cellulase from Trichodermareesei (Declared activity of endoglucanase: $700 \mathrm{EGU} / \mathrm{g}$ ) and pectinase from Aspergillusaculeatus (Declared activity of polygalacturonase: $26000 \mathrm{PG} / \mathrm{ml}$ ) and, were obtained from Novozymes, Denmark and stored at $4{ }^{\circ} \mathrm{C}$.

\subsubsection{Plant material}

Fully ripe L. acidissima fruits were collected from TraVinh province, Vietnam during January in 2014. The weight mean per a fruit was about $400 \mathrm{~g}$. The shell, pulp, seed of fruit was about $29.1 \%, 64.9 \%$ and $6 \%$ respectively. The fruits were stored at $-18{ }^{\circ} \mathrm{C}$ until further use.

\subsection{Methods}

\subsubsection{Experiment procedures}

L. acidissima pulp was removed from the fruits and diluted with water in the ratio of 1:1. A sample mass of $100 \mathrm{~g}$, with $50 \mathrm{~g}$ the pulp and $50 \mathrm{ml}$ of distilled water, was used for each experiment. Then, $\mathrm{pH}$ was adjusted in the range from 3.9 (the natural $\mathrm{pH}$ of L. acidissima pulp) to 5.1 by adding citrate buffer. Temperature was varied in the range from 40 to $60{ }^{\circ} \mathrm{C}$. The combined cellulase-pectinase was added in the range from 0.4 to $2 \%(\mathrm{v} / \mathrm{dwt})$. The samples were placed in a shaking water bath at a rate of 120 strokes per minute, over a time period of 30 to 150 minutes. After the end of the incubation period, the enzymes were inactivated at $85{ }^{\circ} \mathrm{C}$ for 10 mins. The reaction mixture was filtered by the vacuum filtration method through a Whatman filter paper. The juice was weighed to determine moisture (to calculate the efficiency of dry matter recovery) and diluted directly with distilled water for the following analysis tests, DPPH, ABTS and carotenoids [20]. The central value of each variable was chosen by the statistical analysis $(p<0.05)$ with using Stagraphics centurion XVI. Experiments were repeated three times. Results of the central values of the variables were input data to optimize it as the following experimental design.

\subsubsection{Sample preparation to determine the bioactive compounds from the pulp}

Duplicate samples $(25 \mathrm{~g})$ of $L$. acidissima pulp were dried over night at $45{ }^{\circ} \mathrm{C}$. The dried power was grinded and mixed with methanol $(225 \mathrm{ml})$ in a becher. Then it was filtrated through a Whatman filter paper. The extracted juice was diluted with distilled water to a suitable concentration for each of the analysis tests and stored at $4{ }^{\circ} \mathrm{C}$ prior to use [9]. 


\subsubsection{Determination of total phenolic content}

Total phenolic content (TPC) was determined by using Foline-Ciocalteu [9]. An aliquot of sample extract $(0.1 \mathrm{ml})$ was mixed with distilled water $(3 \mathrm{ml})$. and then $0.5 \mathrm{ml}$ of FolineCiocalteu reagent was added. After $3 \mathrm{~min}, 2 \mathrm{ml}$ of sodium carbonate $20 \%$ was added and mixed thoroughly. The tubes were incubated in a boiling water bath $\left(100{ }^{\circ} \mathrm{C}\right)$ for exactly $1 \mathrm{~min}$. It was cooled and the absorbance was measured at $650 \mathrm{~nm}$ by using spectrophotometer (Genesys 6 , Thermo spectroic, USA). The standard curve was linear between 10 and $60 \mathrm{ppm}$ of acid gallic. The results were expressed as milligram $(\mathrm{mg})$ of gallic acid equivalent (GAE) per $100 \mathrm{~g}$ of raw material (L. acidissima pulp). The values were done in triplicate.

\subsubsection{Determine DPPH radical scavenging activity}

DPPH radical scavenging assay was determined by the method developed by BrandWilliams $\mathrm{W}$ et al. [21]. Here, $0.3 \mathrm{ml}$ of each test sample was mixed with $5.7 \mathrm{ml}$ of a DPPHmethanol solution $\left(\mathrm{A}_{515 \mathrm{~nm}}=1.1 \pm 0.02\right)$. Then, the mixtures were vortexed vigorously. Then it was put the dark for 20 mins. The absorbance was determined at $515 \mathrm{~nm}$, and the decreased content of DPPH radical scavenging activity in each concentration of sample could be calculated by the formula as shown:

$$
\% \text { inhibition of the sample }=\left[1-\frac{\text { Asample }}{\text { Acontrol }}\right] * 100
$$

from the equation (1), base on the standard curve: $\%$ inhibition $=a_{1} *$ trolox concentration $+b_{1}$, molecular weight of trolox $=250.29$ and the mass of the extracted juice from $100 \mathrm{~g}$ of the pulp. That deduced DPPH radical cation by TEAC $(\mathrm{mg})$ of the extracted juice sample from $100 \mathrm{~g}$ of the pulp. Where, $a_{1}$ and $b_{1}$ are the coefficients of the standard curve of DPPH.

The standard curve was linear between 100 and $700 \mu \mathrm{M}$ trolox by using spectrophotometer (Genesys 6, Thermo spectroic, USA). The results were expressed in mg (TEAC) per $100 \mathrm{~g}$ of the pulp. Three replicates of each sample were used for statistical analysis and the final chosen values were reported as mean $\pm \mathrm{SD}$.

\subsubsection{Determine Free radical-scavenging ability with using a stable ABTS radical cation}

Free radical scavenging activity was determined by ABTS radical cation decolourisation assay, described by Re R. et al. [22]. ABTS was dissolved in water to a $7 \mu \mathrm{M}$ concentration. ABTS radical cation $\left(\mathrm{ABTS}^{+}\right.$) was produced by reacting $\mathrm{ABTS}$ stock solution with $2.45 \mu \mathrm{M}$ potassium persulfate (final concentration) and kept in the dark at room temperature for $12 \div 16$ hours before use. The radical cation was stable in this form for more than two days in the dark at room temperature. The samples of the $\mathrm{ABTS}^{+}$solution were diluted with redistilled water to an absorbance of $0.70( \pm 0.02)$ at $734 \mathrm{~nm}$ and equilibrated at $30^{\circ} \mathrm{C}$. After the addition of $3.0 \mathrm{ml}$ of diluted $\mathrm{ABTS}^{+}$solution $\left(\mathrm{A}_{734 \mathrm{~nm}}=0.700 \pm 0.02\right)$ to $30 \mu \mathrm{L}$ of the extracts, the absorbance was read exactly in 6 min after the initial mixing by using spectrophotometer (Genesys 6 , Thermo spectroic, USA). The decreased content of ABTS radical scavenging activity in samples could be calculated by the formula as shown:

$$
\% \text { inhibition of the sample }=\left[1-\frac{\text { Asample }}{\text { Acontrol }}\right] * 100
$$

From the equation (2), based on the standard curve: $\%$ inhibition $=a_{2} *$ trolox concentration + $\mathrm{b}_{2}$, molecular weight of trolox $=250.29$ and the mass of the extracted juice from $100 \mathrm{~g}$ of the 
pulp. That deduced ABTS radical cation by TEAC (mg) of the extracted juice sample from 100 $\mathrm{g}$ of the pulp.

Where, $a_{2}$ and $b_{2}$ are the coefficients of the standard curve of ABTS. The standard curve was linear between 100 and $700 \mu \mathrm{M}$ trolox. The results were expressed in mg TEAC per $100 \mathrm{~g}$ of the pulp. All of determinations were performed in triplicate.

\subsubsection{Carotenoids Analysis}

Carotenoids content was analyzed by spectrophotometric method (with the UV/VIS spectrophotometer (Genesys 6, Thermo spectroic, USA) at $440 \mathrm{~nm}$ [23]. Each homogenized sample $(2 \mathrm{~g})$ was placed in a conic retort and $20 \mathrm{ml} 96 \%$ ethanol was added. The sample was stirred on magnetic stirrer for 15 minutes then $25 \mathrm{ml}$ of petrol ether was added and continued to stir for one hour. After $3 \div 4$ hours, both layers were completely divided, the top yellow layer was used for the further analysis of carotenoids at $440 \mathrm{~nm}$. The standard curve was linear between 10 and $60 \mathrm{ppm} \mathrm{K}_{2} \mathrm{Cr}_{2} \mathrm{O}_{7}$. The carotenoids content (mg per $100 \mathrm{~g}$ ) was calculated by equation:

$$
\mathrm{X}=\frac{12.5 .100 \times K E}{36 . a}
$$

where 12.5 and 36 coefficients for the relationship between $\mathrm{K}_{2} \mathrm{Cr}_{2} \mathrm{O}_{7}$ and carotenoids.

$K E$ - carotenoids equivalent by standard curve.

a- sample weight, $g$.

\subsubsection{Methods of nutrient components analysis}

Carbohydrate: by AOAC 986.25 (2011),

Total sugar: by TCVN 4594: 1988,

Reducing sugar: by TCVN 4594: 1988,

Protein: by FAO, 14/7, 1986 page 221,

Lipid: by FAO, 14/7, 1986 page 222,

Calcium: by AOAC 968.08 (2011),

Cellulose: by TCVN 5103:1990,

Pectin: by calcium pectate method.

2.2.8. The dry matter recovery efficiency $(Y)$ from hydrolysis was calculated by equation

$$
\mathrm{Y}(\%)=\frac{\text { the yield of dry matter in the extracted juice }}{\text { the yield of dry matter in the pulp }} * 100
$$

The dry matter content in the extracted juice $(\%)=(100$ - moisture content in the extracted juice $)$ $\%$; The dry matter content in the pulp $(\%)=(100-$ moisture content in the pulp $) \%$; The yield of dry matter in the extracted juice $=$ The dry matter content in the extracted juice $*$ the weight of the extracted juice / 100; The yield of dry matter in the pulp $=$ The dry matter content in the pulp $*$ the weight of the pulp / 100. 


\subsubsection{Experimental design}

Response surface methodology (RSM) with star distance of Circumscribed Central Composite (CCC) designs was used to carry out the experiments to optimize the enzymatic hydrolysis conditions, The independent variables were coded $\mathrm{pH}\left(\mathrm{Z}_{1}\right)$, incubation temperature $\left(\mathrm{Z}_{2}\right)$, enzymes concentration $\left(Z_{3}\right)$, incubation time $\left(Z_{4}\right)$. The range and central point value of all the three process variables are shown in Table 1 . The variables were coded according to the following equation:

$$
x_{j}=\frac{Z_{j}-Z_{0}}{\Delta Z_{j}}, j=1,2,3, \ldots k
$$

where, $x_{j}$ is the dimensionless coded value, $Z_{j}$ is the actual value of variables, $Z_{0}$ is the actual value of variables at the center point, and $\Delta \mathrm{Z}$ is the step change value. After the conduct of the experiment, the data was fitted with a second-order polynomial equation as follow:

Table 1. The range of variables in Circumscribed Central Composite design.

\begin{tabular}{lccccccc}
\hline \multirow{2}{*}{ Independent variables } & \multirow{2}{*}{ Unit } & Symbol & \multicolumn{7}{c}{ Code level } \\
\cline { 5 - 8 } & & & $-\alpha$ & -1 & 0 & 1 & $+\alpha$ \\
\hline $\mathrm{pH}$ & $\mathrm{Z}_{1}$ & 3.6 & 3.9 & 4.2 & 4.5 & 4.8 \\
\hline Incubation temperature & ${ }^{\circ} \mathrm{C}$ & $\mathrm{Z}_{2}$ & 35 & 40 & 45 & 50 & 55 \\
\hline Enzymes concentration & $\mathrm{v} / \mathrm{dwt}$ & $\mathrm{Z}_{3}$ & 0.4 & 0.8 & 1.2 & 1.6 & 2.0 \\
\hline Incubation time & $\mathrm{min}$ & $\mathrm{Z}_{4}$ & 30 & 60 & 90 & 120 & 150 \\
\hline
\end{tabular}

Table 2. Circumscribed Central Composite design with experimental and predicted values for the efficiency of extracted dry matter.

\begin{tabular}{|c|c|c|c|c|c|c|}
\hline \multirow[b]{2}{*}{$\begin{array}{l}\text { Run } \\
\text { order }\end{array}$} & \multicolumn{4}{|c|}{ Coded variables } & \multicolumn{2}{|c|}{ Response $(\mathrm{Y}(\%))$} \\
\hline & $\begin{array}{l}\left(\mathrm{x}_{1}\right) \\
\mathrm{pH}\end{array}$ & $\begin{array}{c}\left(\mathrm{x}_{2}\right) \\
\text { temperature }\end{array}$ & $\begin{array}{c}\left(\mathrm{x}_{3}\right) \\
\text { Combined } \\
\text { enzymes } \\
\text { concentration }\end{array}$ & $\left(\mathrm{x}_{4}\right)$ Time & $\begin{array}{l}\text { Experimental } \\
\text { values }\end{array}$ & $\begin{array}{l}\text { Predicted } \\
\text { values from } \\
\text { the model }\end{array}$ \\
\hline N1 & -1 & -1 & -1 & -1 & $46.87 \pm 0.77$ & 46.99 \\
\hline $\mathrm{N} 2$ & 1 & -1 & -1 & -1 & $49.42 \pm 1.78$ & 49.50 \\
\hline N3 & -1 & 1 & -1 & -1 & $50.69 \pm 1.27$ & 49.82 \\
\hline N4 & 1 & 1 & -1 & -1 & $50.75 \pm 0.52$ & 50.62 \\
\hline N5 & -1 & -1 & 1 & -1 & $48.08 \pm 0.83$ & 48.50 \\
\hline N6 & 1 & -1 & 1 & -1 & $50.70 \pm 0.66$ & 50.15 \\
\hline N7 & -1 & 1 & 1 & -1 & $51.15 \pm 0.72$ & 50.79 \\
\hline N8 & 1 & 1 & 1 & -1 & $50.38 \pm 0.46$ & 50.72 \\
\hline
\end{tabular}




\begin{tabular}{|c|c|c|c|c|c|c|}
\hline N9 & -1 & -1 & -1 & 1 & $48.44 \pm 1.33$ & 48.14 \\
\hline N10 & 1 & -1 & -1 & 1 & $49.82 \pm 0.68$ & 50.14 \\
\hline N11 & -1 & 1 & -1 & 1 & $49.53 \pm 0.50$ & 50.04 \\
\hline N12 & 1 & 1 & -1 & 1 & $50.71 \pm 0.42$ & 50.32 \\
\hline N13 & -1 & -1 & 1 & 1 & $50.76 \pm 0.04$ & 50.85 \\
\hline N14 & 1 & -1 & 1 & 1 & $51.07 \pm 0.37$ & 51.98 \\
\hline N15 & -1 & 1 & 1 & 1 & $52.25 \pm 0.50$ & 52.20 \\
\hline N16 & 1 & 1 & 1 & 1 & $51.78 \pm 0.23$ & 51.62 \\
\hline N17 & -2 & 0 & 0 & 0 & $46.12 \pm 0.55$ & 46.34 \\
\hline N18 & +2 & 0 & 0 & 0 & $48.48 \pm 0.22$ & 48.27 \\
\hline N19 & 0 & -2 & 0 & 0 & $47.65 \pm 1.56$ & 47.11 \\
\hline N20 & 0 & +2 & 0 & 0 & $49.03 \pm 0.43$ & 49.58 \\
\hline $\mathrm{N} 21$ & 0 & 0 & -2 & 0 & $50.54 \pm 0.28$ & 50.87 \\
\hline $\mathrm{N} 22$ & 0 & 0 & +2 & 0 & $54.01 \pm 0.38$ & 53.68 \\
\hline N23 & 0 & 0 & 0 & -2 & $51.18 \pm 0.41$ & 51.65 \\
\hline $\mathrm{N} 24$ & 0 & 0 & 0 & +2 & $54.17 \pm 0.16$ & 53.70 \\
\hline $\mathrm{N} 25$ & 0 & 0 & 0 & 0 & $54.08 \pm 0.37$ & 54.02 \\
\hline $\mathrm{N} 26$ & 0 & 0 & 0 & 0 & $54.09 \pm 0.10$ & 54.02 \\
\hline $\mathrm{N} 27$ & 0 & 0 & 0 & 0 & $53.95 \pm 0.28$ & 54.02 \\
\hline $\mathrm{N} 28$ & 0 & 0 & 0 & 0 & $53.99 \pm 0.30$ & 54.02 \\
\hline $\mathrm{N} 29$ & 0 & 0 & 0 & 0 & $54.01 \pm 0.38$ & 54.02 \\
\hline N30 & 0 & 0 & 0 & 0 & $54.05 \pm 0.11$ & 54.02 \\
\hline N31 & 0 & 0 & 0 & 0 & $53.99 \pm 0.42$ & 54.02 \\
\hline
\end{tabular}

$\mathrm{Y}(\%)=\beta_{0}+\sum_{i=1}^{4} \beta_{i} x_{i}+\sum_{i=1}^{4} \beta_{i i} x_{i}{ }^{2}+\sum_{i=1}^{3} \sum_{j=1+1}^{4} \beta_{\mathrm{ij}} x_{\mathrm{i}} x_{\mathrm{j}}$

where $\mathrm{Y}(\%)$ is the predicted response, $\beta_{0}$ is the model constant, $\beta_{\mathrm{i}}, \beta_{\mathrm{ii}}$ and $\beta_{\mathrm{ij}}$ are model coefficients.

\subsubsection{Data analysis}

The design of experiments, analysis of the results and prediction of the responses were carried out using Modde 5.0 software. Comparisons of means were performed by one-way ANOVA (analysis of variance) followed by Tukey's test ( $p$-value $<0.05$ ). 


\section{RESULTS AND DISCUSSION}

In this study, the relationship between the variables and the response function were identified by four factors inscribed central composite design. Further, the hydrolysis conditions were optimized.

The analysis results of cellulose and pectin contents in the pulp were $1.94 \%$ and $3.87 \%$ respectively. With these obtained results, we conducted a study to find the suitable cellulase/pectinase ratio in the conditions $\mathrm{Z}_{1}=4.2, \mathrm{Z}_{2}=45{ }^{\circ} \mathrm{C}, \mathrm{Z}_{3}=0.8 \%$ (v/dwt), $\mathrm{Z}_{4}=60 \mathrm{~min}$. The control sample conducted with $Z_{3}=0 \%$. Results are shown in Table 3 .

Table 3. Effect of the ratio of cellulase/pectinase to the efficiency of dry matter recovery.

\begin{tabular}{lcccccccc}
\hline $\begin{array}{l}\text { cellulase } \\
\text { /pectinase }\end{array}$ & $0 / 0$ & $0 / 1$ & $1 / 0$ & $1 / 1$ & $1 / 2$ & $2 / 1$ & $1 / 3$ & $3 / 1$ \\
\hline $\mathrm{Y}(\%)$ & $31.8 \pm 0.9^{\mathrm{d}}$ & $48.3 \pm 0.2^{\mathrm{c}}$ & $47.9 \pm 0.5^{\mathrm{c}}$ & $51.9 \pm 0.3^{\mathrm{a}}$ & $51.6 \pm 0.2^{\mathrm{ab}}$ & $50.80 \pm 0.6^{\mathrm{b}}$ & $51.0 \pm 0.2^{\mathrm{ab}}$ & $50.83 \pm 0.6^{\mathrm{b}}$ \\
\hline
\end{tabular}

Note: * Means of triplicate determination \pm SD. ${ }^{a}$ highest significant value; ${ }^{b, c, ~}{ }^{d}$ lower significant value.

Table 3 showed that the efficiency of dry matter recovery achieved the highest value at the ratio of cellulase/pectinase $=1 / 1$ and the lowest value at the control sample. This was explained that enzymes helped to reduce viscosity of the samples rapidly and increase the reaction rate of hydrolysis, resulting in increasing the efficiency of dry matter recovery. We chose this value to optimize the hydrolysis conditions. Table 2 showed that the efficiency of dry matter recovery ranged from 46.12 to $54.17 \%$ on dry weight basis and the maximum efficiency was reached for the $24^{\text {th }}$ run under the experimental conditions of $\mathrm{Z}_{1}=4.2, \mathrm{Z}_{2}=45^{\circ} \mathrm{C}, \mathrm{Z}_{3}=1.2 \%(\mathrm{v} / \mathrm{dwt}), \mathrm{Z}_{4}=$ $120 \mathrm{~min}$. The lowest efficiency was observed for the $17^{\text {th }}$ run with the following conditions of $Z_{1}$ $=3.6, \mathrm{Z}_{2}=45^{\circ} \mathrm{C}, \mathrm{Z}_{3}=1.2 \%$ (v/dwt), $\mathrm{Z}_{4}=90 \mathrm{~min}$. Based on these data, the hydrolysis process was optimized for obtaining desirable response at maximum.

\subsection{Fitting the model}

Table 4. The fitted quadratic model in terms of coded variables for $\mathrm{Y}(\%)$ responses.

\begin{tabular}{lllcccc}
\hline Responses & $2^{\text {nd }}$ Order polynomial equation & & $\begin{array}{c}\text { Regression } \\
\text { (p-value) }\end{array}$ & $\mathrm{R}^{2}$ & $\begin{array}{c}\mathrm{R}^{2} \\
\text { (adjusted) }\end{array}$ \\
\hline $\mathrm{Y}(\%)$ & $54.021+0.482195 \mathrm{Z}_{1}+0.617427 \mathrm{Z}_{2}+$ & & 0.000 & 0.974 & 0.952 \\
& $0.703791 \mathrm{Z}_{3}+0.512901 \mathrm{Z}_{4}-0.428921 \mathrm{Z}_{1} \mathrm{Z}_{2}{ }^{2}$ & & & & \\
& $0.298328 \mathrm{Z}_{3} \mathrm{Z}_{4}-1.67949 \mathrm{Z}_{1}^{2}-1.42019 \mathrm{Z}_{2}^{2}-$ & & & \\
& $0.436517 \mathrm{Z}_{3}^{2}-0.336722 \mathrm{Z}_{4}^{2}$ & & & & \\
\hline
\end{tabular}

Table 2 indicated that the results of the predicted and experimental responses for the 31 runs according to the experimental design. Overall, a close relationship between the experimental and predicted values indicated satisfactory of model developed. The predicted quadratic model in terms of coded variables was given in Table 4.

The statistical analysis showed that the proposed model was highly significant (P-value < $0.001)$ and a very high $F$-value $(F=43.3917)$. The coefficient of determination $R^{2}=0.974$ 
indicated the compatibility of model. The value of adjusted determination coefficient $\mathrm{R}^{2}$ (adj) was 0.952 , which also confirmed that the model was highly significant [10]. The effects of independent variables and their mutual interaction on the efficiency of the dry matter recovery can be seen on the response surface and contour plots as shown in Fig. 1.

the efficiency of dry matter recovery

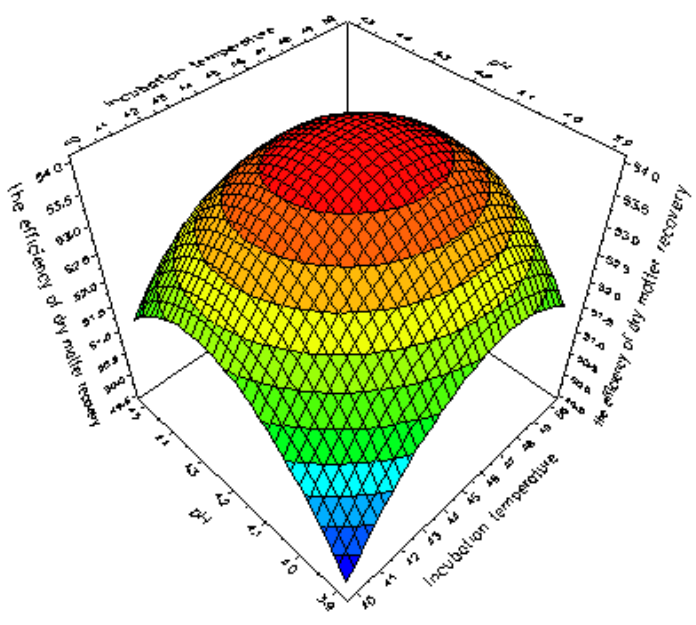

a

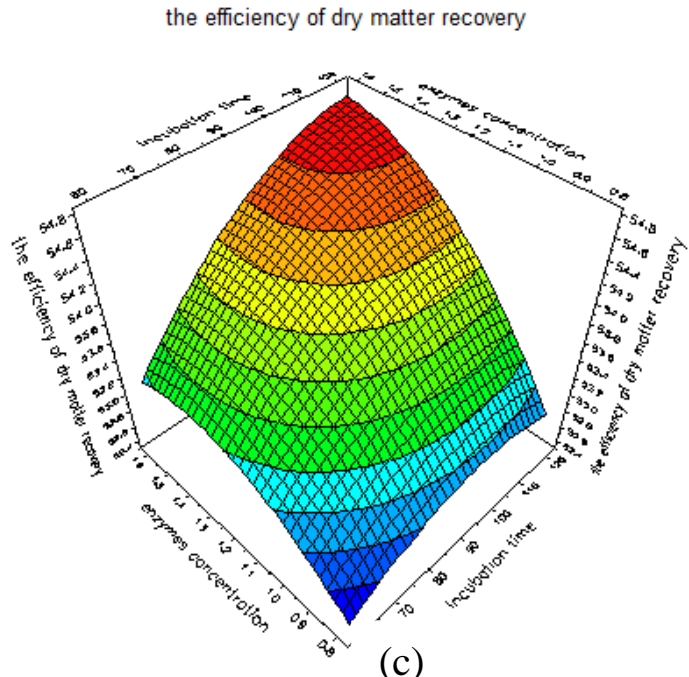

(c)

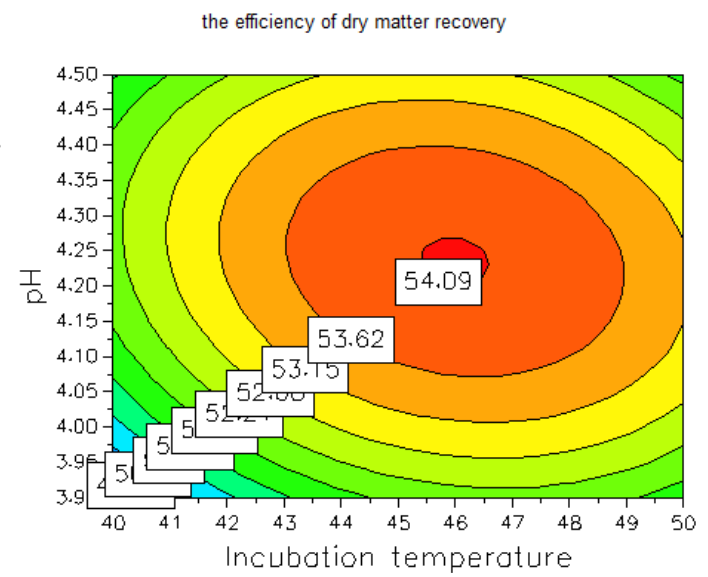

$\mathrm{b}$

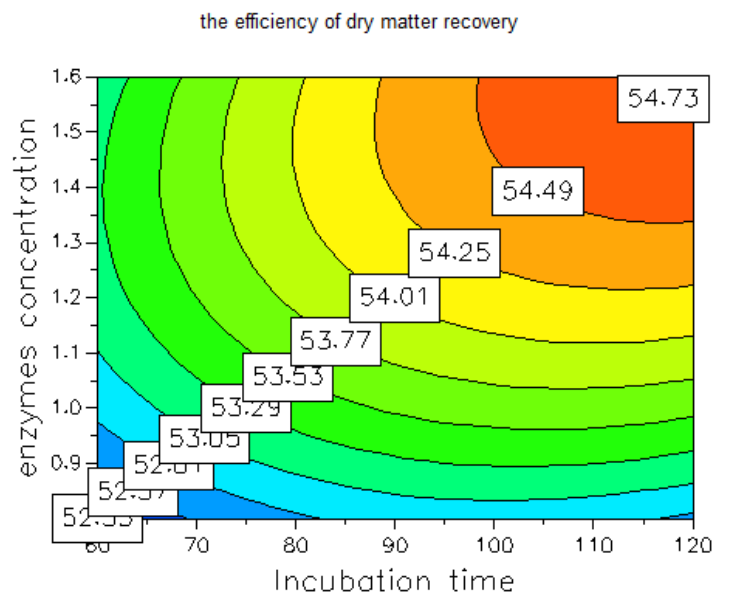

(d)

Figure 1. The interactive effect of $\mathrm{pH}$ and incubation temperature ((a) and (b)), combined enzymes concentration and incubation time ((c) and (d)) of hydrolysis process on the efficiency of the dry matter recovery from L. acidissima pulp.

From Figure 1 and Table 4 it could be deduced that factors such as $\mathrm{pH}$, incubation temperature, combined enzymes concentration and incubation time significantly contributed to affect the dry matter recovery. the optimal conditions for the hydrolysis were derived at $\mathrm{pH}=$ 4.2 , incubation temperature $=45{ }^{\circ} \mathrm{C}$, combined enzymes concentration $=1.6 \%(\mathrm{v} / \mathrm{dwt})$ and incubation time $=120$ minutes, then the efficiency in the prediction of model was $54.76 \%$. This result was no significant difference in compared with the experimental value $(54.69 \pm 0.12 \%$, 
$p<0.05)$, that showed a close relationship between the experimental values and the predicted values and indicated the satisfaction of the developed model. The use of the combined enzymes increased the efficiency of the dry matter recovery from L. acidissima pulp up to $20.89 \%$ with respect to the efficiency from non-enzymatic extraction $(\mathrm{Y}=33.8 \pm 2 \%)$ as shown in Table 5. Our results were in accordance with the earlier report by Chadha $\mathrm{R}$ et al. [24].

Table 5. Response value under optimal conditions.

\begin{tabular}{lllll}
\hline \multirow{2}{*}{ Responses } & \multicolumn{2}{l}{ Enzymatic extraction } & & Non-enzymatic extraction* \\
\cline { 2 - 3 } & Predicted value & $\begin{array}{l}\text { Experimental } \\
\text { value* }\end{array}$ & & $\begin{array}{l}\text { Experimental value* } \\
\text { Y }\end{array}$ \\
\hline
\end{tabular}

* Means of triplicate determination \pm SD.

\subsection{The effect of the optimal extraction conditions on nutrient components recovery}

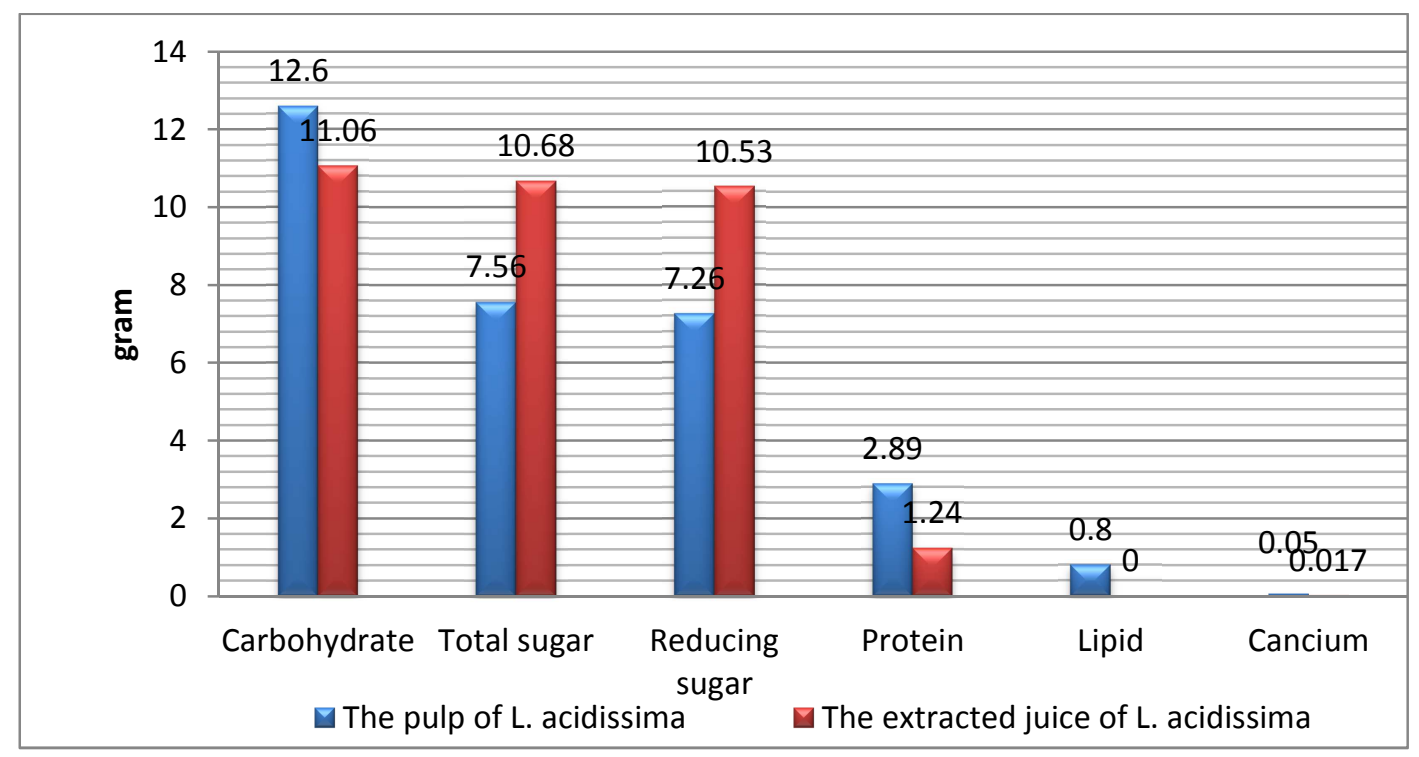

Figure 2. The nutrient components of $100 \mathrm{~g}$ L. acidissima pulp and extracted juice from $100 \mathrm{~g}$ the pulp.

The results in Fig. 2 showed that the carbohydrate, total sugar, reducing sugar, protein and calcium content in the extracted juice reached 11.06, 10.68, 10.53, 1.24, $0.017 \mathrm{~g}$, and the efficiency achieved $87.74 \%, 141.29 \%, 145.07 \%, 42.96 \%$ and $34 \%$, respectively. The results could be explained that the enzymes broke down complex polysaccharides of plant tissues into simpler molecules like galacturonic acids, glucose, dextrin, maltose [25]. So, the total contents of sugar and reducing sugar of extracted juice were higher than of the pulp of L. acidissima. Besides, the efficiency of carbohydrate recovery was high. Otherwise, the combined enzymes treatment caused breaking of carbohydrate-protein complexes, so the positively charged proteins became partially exposed on the particle surface, promoting flocculation, which reduced the efficiency of protein recovery. 


\subsection{The effect of the optimal conditions of the extraction on total polyphenol, carotenoids content, DPPH and ABTS radical scavenging activities}

Figure 3 illustrated that the use of combined cellulase-pectinase not only significantly increased the dry matter recovery but also dramatically increased bioactive compounds. In the optimal conditions of the enzymatic hydrolysis, the total phenolic compounds, antioxidant capacity by DPPH, ABTS method and carotenoids dramatically rose from 53.5 to $106.7 \mathrm{mg}$, 27.7 to $67.1 \mathrm{mg}$ (TEAC), 31.9 to $102.1 \mathrm{mg}$ (TEAC) and 48 to $86.6 \mathrm{mg}$. That increased $41.0 \%$, $30.2 \%, 40.3 \%$ and $22.2 \%$ respectively in compared with control sample (without enzyme). That contributed to enrich nutrients in the extracted juice for health benefits from L. acidissima pulp. The major antioxidant nutrients of L. acidissima fruits are component having strong antioxidant capacity. In general, the TEAC by DPPH method was lower than by ABTS. That results were in good agreement with the earlier report [10].

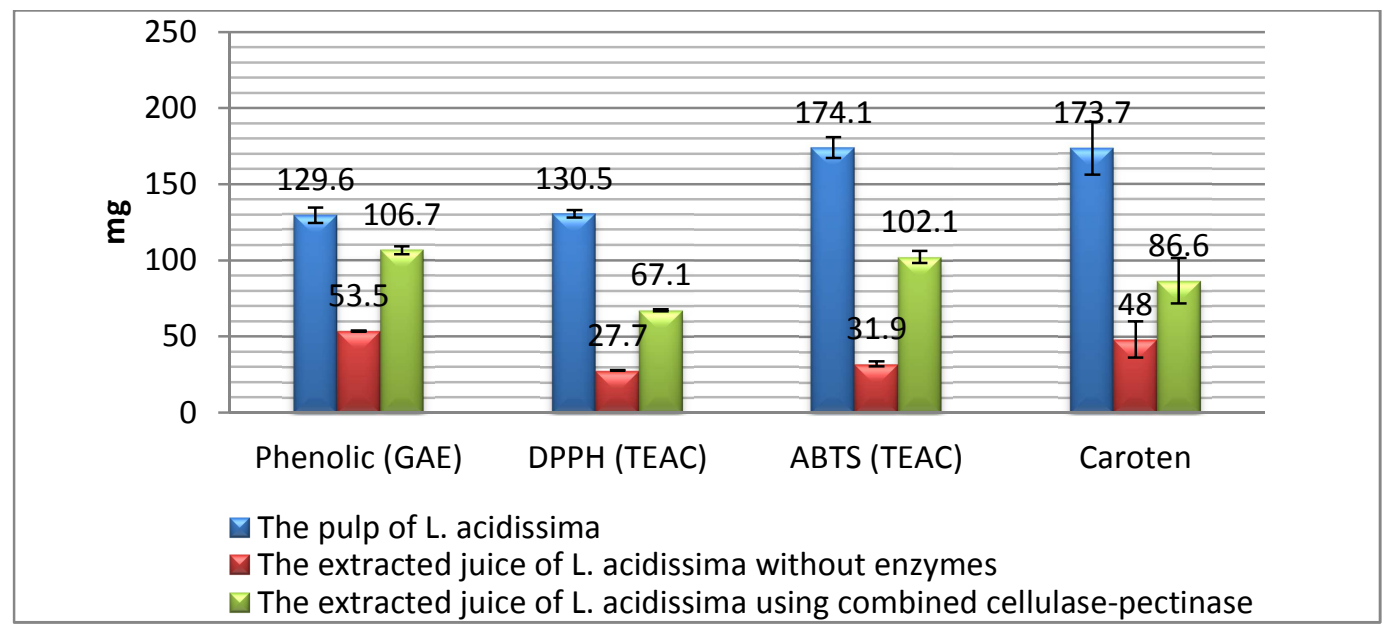

Figure 3. Total phenolic compounds, carotenoids, and antioxidant activities of $100 \mathrm{~g}$ of the pulp and the juice from $100 \mathrm{~g}$ of the pulp.

\section{CONCLUSIONS}

This study showed that the use of combined pectinase-cellulase for the hydrolysis (the ratio of $1 / 1$ respectively) at optimal conditions of $\mathrm{pH}=4.2$, incubation temperature $=45{ }^{\circ} \mathrm{C}$, the combined enzymes concentration $=1.6 \%(\mathrm{v} / \mathrm{dwt})$ and incubation time $=120$ minutes caused the significant increase up to $20.89 \%$ in the efficiency of dry matter recovery of the extracted juice from 33.8 to $54.69 \%$,and there were significant increase in phenolic compounds, carotenoids content and the bioactive compounds by DPPH, ABTS method. That average increased $41.0 \%$, $30.2 \%, 40.3 \%$ and $22.2 \%$ respectively as compared to the control sample. The treatment of combined pectinase and cellulose can achieve high efficiency and can be used to produce many products from $L$. acidissima pulp.

Acknowledgement. This study was funded by TraVinh University, Vietnam, and experiments were conducted in the laboratory of Viet Nam Nat. Uni. Ho Chi Minh City University of Technology. We are thankful for the support and encouragement rendered. 


\section{REFERENCES}

1. Senthilkumar A. and Venkatesalu V. - Chemical constituents, in vitro antioxidant and antimicrobial activities of essential oil from the fruit pulp of wood apple. Industrial Crops and Products 46 (2013) 66-72.

2. Prathapan A., Krishna M.S., Nisha V.M. - Sundaresan A, Raghu KG, Polyphenol rich fruit pulp of Aegle marmelos(L.) Correa exhibits nutraceutical properties to down regulate diabetic complications-An in vitro study. Food Research International 48 (2012) 690695.

3. Ratnayake R.M.R.N.K., Sumithra H.J., Fernando M.D., Palipane K.B. - Effect of GRAS compounds on Aspergillus rot of wood-apple (Feronia limonia). Phytopar-Asitica 37 (2009) 431-436.

4. Pandey S., Satpathy G. and Gupta R.K. -Evaluation of nutritional, antioxidant and antibacterial activity of exotic fruit "Limonia acidissima". Journal of Pharmacognosy and Phytochemistry 3 (2014) 81-88.

5. Vijayvargia P., Choudhary S. and Vijayvargia R. - Preliminary phytochemical screening of Limonia acidissima linn. International Journal of Pharmacy and Pharmaceutical Sciences 6 (2014) 134-136.

6. Islam M.M., Shams B., Siraj S., Hasan M.K., Masum S.M. and Chowdhury J.U., Comparative Study of Minerals Content in Green and Ripe Bael (Wood Apple) Powder. International Journal of Basic \& Applied Sciences 11 (2011) 133-136.

7. Lambole V.B., Murti K., Bhatt U.K., Kumar S.P. and Gajera V. - Phytopharmacological properties of Aegle marmelose as a potent medicinal tree. International Journal of Pharmaceutical Sciences Review and Research 5 (2010) 67-72.

8. Charoensiddhi S. and Anprung P. - Bioactive compounds and volatile compounds of Thai bael fruit (Aegle marmelos (L.) Correa) as a valuable source for functional food ingredients. International Food Research Journal 15 (2008) 287-295.

9. Darsini D.T.P., Maheshu V., Vishnupriya M., Nishaa S., Sasikumar J.M. - Antioxidant potential and amino acid analysis of underutilized tropical fruit Limonia acidissima L.. Free Radicals and Antioxidants 3 (2013) 62-69.

10. Ilaiyaraja N., Likhith K.R., Sharath Babu G.R., Khanum F. - Optimisation of extraction of bioactive compounds fromFeronia limonia (wood apple) fruit using response surface methodology (RSM). Food Chemistry 173 (2015) 348-354.

11. Bapadopoulou A. and Frazier R.A. - Characterization of Characterization of interactions. Trends in Food Science \& Technology 15 (2004) 186-190.

12. Oussalah M., Caillet S., Lacroix M. - Mechanism of action Spanish oregano, Chinese cinnamon, and savory essential oils against cell membrane and walls of E. coli O157:H7 and Listeria monocytogenes. J. Food Prot. 69 (2006) 1046-1055.

13. Panda H. - Medicinal Plants Cultivation and Their Uses. New Delhi: Asia pacific Business Press Inc (2000).

14. Sreenath H.K. and Radola B.J. - The effect of removing cellulase(s) from a commercial pectinase on maceration and liquefaction of carrots. Journal of Biotechnology 4 (1986) 269-282.

15. Kilara A. - Enzymes and their uses in the processed apple industry: a review. Process Biochem. 17 (1982) 35-41. 
16. Will F., Bauckhage K. and Dietrich H. - "Apple pomace liquefaction with pectinases and cellulases:analytical data of the corresponding juices. European Food Research and Technology 211 (2000) 291-297.

17. Sreenath H.K., Sudarshanakrishna K.R., and Santhanam K. - Improvement of Juice Recovery from pineapple pulp/residue using cellulases and pectinases. Journal of fermentation and bioengineering 78 (1994) 486-488.

18. Liu Z., Dang J., Wang Q., Yu M., Jiang L., Mei L., Shao Y. and Tao Y. - Optimization of polysaccharides from Lycium ruthenicum fruit using rsm and its anti-oxidant activity. International Journal of Biological Macromolecules 61 (2013) 127-134.

19. You Q., Yin X., Zhao Y. - Enzyme assisted extraction of polysaccharides from the fruit of Cornus officinalis. Carbohydrate Polymers 98 (2013) 607-610.

20. Pham N.B., Nguyen PK and Dong D.T.A. - Impact of the hydrolysis conditions on the recovery efficiency of the dry matter, total phenolic content, DPPH and ABTS radicalscavenging activities from Limonia acidissima fruits. Journal of Biotechnology 14 (2016) 479-486.

21. Brand-Williams W, Cuvelier ME and Berset C- Use of a free radical method to evaluate antio-xidant activity. Food Science and Technology 28 (1995) 25-30.

22. Re R., Pellegrini N., Proteggente A., Pannala A., Yang M. and Rice-Eans C. - Antioxidant activity applying an improved ABTS radical cation decolorization assay. Free Radical Biology \& Medicine 26 (1999) 1231-1237.

23. Murniece I., Kruma Z., Skrabule I. - Carotenoids and Colour Before and After Storage of Organically and Conventionally Cultivated Potato Genotypes in Latvia. World Academy of Science, Engineering and Technology International Journal of Biological, Veterinary, Agricultural and Food Engineering 6 (2012) 94-98.

24. Chadha R., Kumbhar B.K., Sarkar B.C. - Enzymatic hydrolysis of carrot for increased juice recovery. J. Food Sci. Techno. 40 (2003) 35-39.

25. Dey T.B. and banerjee R. - Application of decolourized and partially purified polygalacturonase and anpha amylase in apple juice clarification. Brazilian journal of microbiology 45 (2014) 97-104.

\section{TÓM TẮT}

\section{TỐI UUU HÓA CÁC ĐIỀU KIÊN THỦY PHÂN BẰNG ENZYME ĐỂ GIA TĂNG HIÊU SUẤT THU HỒI CHẤT KHỒ TƯ THỊT QUẢ TRÁI QUÁCH VỚI SỰ KẾT HỢP CỦA CELLULASE VÀ PECTINASE SƯ DỤNG PHƯONG PHÁP BỀ MẬT ĐÁP ỨNG}

$$
\text { Phạm Bảo Nguyên }{ }^{1, *} \text {, Đống Thị Anh Đào² }
$$

${ }^{1}$ Trung tâm Công nghệ sau thu hoạch, Trương Đại học Trà Vinh, 126 quốc lộ 53, Phwờng 5, Thành phố Trà Vinh, Tỉnh Trà Vinh, Việt Nam

${ }^{2}$ Bộ môn công nghệ thực phẩm, Trường Đại học Bách khoa, Đại học quốc gia Thành phố Hồ Chí Minh, Việt Nam

*Email: pbnguyen@tvu.edu.vn 
Trái quách chứa nhiều dinh dưỡng và các hợp chất có hoạt tính sinh học. Trong nghiên cứu này, quá trình thủy phân thịt quả trái quách đã được khảo sát nhằm làm tăng hiệu suất thu hồi chất khô và các hợp chất có hoạt tính sinh học bằng việc kết hợp cellulase và pectinase. Việc khảo sát các điều kiện thủy phân bằng enzyme đã được tối ưu hóa bằng phương pháp bề mặt đáp ứng. Các biến độc lập được mã hóa như: $\mathrm{pH}\left(\mathrm{x}_{1}\right)$, nhiệt độ ủ $\left(\mathrm{x}_{2}\right)$, tồng nồng độ cellulase và pectinase $\left(\mathrm{x}_{3}\right)$ (với tỉ lệ cellulase/pectinasae $\left.=1 / 1\right)$, và thời gian thủy phân $\left(\mathrm{x}_{4}\right)$. Các biến mã hóa này tương ứng với các biến thực $\mathrm{Z}_{1}, \mathrm{Z}_{2}, \mathrm{Z}_{3}$ và $\mathrm{Z}_{4}$. Kết quả phân tích phương sai thể hiện rằng các điều kiện thủy phân tác động có ý nghĩa đến hiệu suất thu hồi chất khô. Điều kện tối ưu được chọn là $\mathrm{Z}_{1}=4,2, \mathrm{Z}_{2}=45^{\circ} \mathrm{C}, \mathrm{Z}_{3}=1,6 \%(\mathrm{v} / \mathrm{dwt})$ và $\mathrm{Z}_{4}=120$ phút. Tại điều kiện tối ưu này, hiệu suất thu hồi chất khô theo dự đoán của mô hình đạt $54,76 \%$ và nó không có sự khác biệt ý nghĩa so với hiệu suất từ thực nghiệm $(54,59 \%)$. Hiệu suất từ thực nghiệm này tăng $20,89 \%$ so với hiệu suất từ quá trình trích li không sử dụng enzyme. Bên cạnh đó, hiệu suất thu hồi carbohydrat đạt $87,74 \%$. Hơn nữa, dịch quả trích li chứa tổng hàm lượng phenolic, carotene, hoạt tính chống oxi hóa theo phương pháp DPPH và ABTS đạt ở mức cao, tương ứng là 106,7 mg GAE, 86,6 $\mathrm{mg}, 67,1$ và $102,1 \mathrm{mg}$ tương đương trolox từ $100 \mathrm{~g}$ thịt quả ban đầu.

Tì khóa: tối ưu, cellulase, pectinase, trái quách, DPPH, ABTS. 